\title{
Influence of the Small Amounts of Impurities in High Purity Aluminium on the Dielectric Film of Electrolytic Condenser (Report I)
}

\author{
Namio Kawashtma and Yuzo NaKamura \\ Toyô Aluminium $K . K$. \\ Tomota NISHI and Katsuji Nishino \\ The Department of Industrial Chemistry, Kyoto University \\ (Received January 25, 1951) \\ SYNOPSIS
}

\begin{abstract}
Many factors affecting the dielectric property of electrolytic condenser were considered, among which the purity of aluminium used as anode, was the most important. It is usual to use in Japan a very pure aluminium, $99.9 \%$ up. It is not, however, clear which should be the most effective on the dielectric property of anode among the main impurities of iron, silicon and copper. Therefore, the authors carried out the experiments to investigate the influence of the small amounts of these impurities (0.02 0.1\%) on the dielectric film of electrolytic condenser and to ascertain which impurity should be the most unfavourable to the formation of dielectric film.

It was found that the small amounts of the impurities dissolved in solid solution as copper and silicon had no effect, but the existence of precipitate as iron gave a worse effect on the dielectric property.
\end{abstract}

\section{Introduction}

It seems that the formation of the dielectric film is injured by the impurities in aluminium. Therefore, the purity of aluminium used as the anode in electrolytic condenser should be higher than 99.9 percent. Numerous research papers have been published on this subject by Siegmund(1), Miyata( ${ }^{(2)}$, Georgiev ${ }^{(3)}$, Notwotny and Holik ${ }^{(4)}$ and others, but it is not clear which impurity should be the most effective on the dielectric property among the main impurities of iron, silicon and copper and the influence of their states of existence (compound or solid solution) is not also clear. So far as the authors are aware, the systematic research has not yet been made in the influence of the grain size of high purity aluminium on the dielectric property of electrolytic condenser.

Some examples of the compositions of high purity aluminium foils used for the

Table 1 Chemical Composition of High Purity Auminium Foils.

\begin{tabular}{|c|c|c|c|c|}
\hline \multicolumn{4}{|c|}{ Chemical Composition \% } & \multirow{2}{*}{$\begin{array}{c}\text { Manufactured } \\
\text { in }\end{array}$} \\
\hline $\mathrm{Fe}$ & $\mathrm{Si}$ & $\mathrm{Cu}$ & $\begin{array}{c}\text { A] } \\
\text { (Rem) }\end{array}$ & \\
\hline 0.031 & 0.032 & 0.016 & 99.921 & \multirow{4}{*}{ April } \\
\hline 0.029 & 0.027 & 0.019 & 99.925 & \\
\hline 0.032 & 0.048 & 0.015 & 99.905 & \\
\hline 0.025 & 0.041 & 0.021 & 99.913 & \\
\hline 0.022 & 0.029 & 0.017 & 99.932 & \multirow{5}{*}{ May } \\
\hline 0.021 & 0.023 & 0.015 & 99.941 & \\
\hline 0.019 & 0.025 & 0.016 & 99.940 & \\
\hline 0.017 & 0.020 & 0.022 & 99.941 & \\
\hline 0.018 & 0.014 & 0.024 & 99.944 & \\
\hline
\end{tabular}

electrolytic condenser in Japan are shown in Table 1. The electrolytic condenser made in foreign countries is superior to that made in Japan.

The reason why such a difference exists between them is not evident. Factors affecting the dielectric property of electrolytic condenser may be considered to be as follows :

(1) H.O. Siegmund, Trans. Amer. Fle. Soc., 53 (1928),203.

(2) A. Denkikagaku, (Japan), 1935.

(3) Alexander M. Georgiev, Electrolytic Capacitor, 1945 Edition.

(4) H. Notwotny and L. Holik, Mikroskopie (Germany), 5(1950), 31. 
Purity of Jaluminium; Surface conditions of aluminium foil; Concentration, quality and purity of electrolyte; Conditions of formation and, etc.

The authors, therefore, carried out to investigate the influence of the small amounts of impurities ( $\mathrm{Fe}, \mathrm{Si}$ and $\mathrm{Cu}$ ) on the dielectric film of electrolytic condenser to ascertain which impurity should be most unfavourable to the formation of dielectric film.

The influence of other impurities such as $\mathrm{Mg}, \mathrm{Zn}, \mathrm{Ti}$ and $\mathrm{Mn}$, and the effect of grain size on the dielectric property will be reported in next paper.

\section{Preparation of Material}

The high purity aluminium (99.99\%) made by Nissin Chemical Industries, Limited and

Table 2 Result of Chemical Analysis.

\begin{tabular}{|c|c|c|c|c|}
\hline \multirow{2}{*}{$\begin{array}{l}\text { No. of } \\
\text { Specim- } \\
\text { en }\end{array}$} & \multicolumn{4}{|c|}{ Composition (\%) } \\
\hline & $\mathrm{Cu}$ & $\mathrm{Fe}$ & $\mathrm{Si}$ & $A !(R)$ \\
\hline (1) & 0.002 & 0.002 & 0.007 & 99.989 \\
\hline (2) & $\begin{array}{r}(0.01) \\
0.008\end{array}$ & 0.003 & 0.033 & 99.956 \\
\hline (3) & $\begin{array}{r}(0.03) \\
0.031\end{array}$ & 0.007 & 0.015 & 99.947 \\
\hline (4) & $\begin{array}{l}(0.05) \\
0.050\end{array}$ & 0.009 & 0,009 & 99.932 \\
\hline (5) & $\begin{array}{r}(0.08) \\
0.087\end{array}$ & 0.007 & 0.009 & 99.897 \\
\hline (6) & $\begin{array}{r}(0.10) \\
0.100\end{array}$ & 0.010 & 0.008 & 99.882 \\
\hline (7) & 0.005 & $\begin{array}{r}(0.01) \\
0.009\end{array}$ & 0.009 & 99.977 \\
\hline (8) & 0.003 & $\begin{array}{r}(0.03) \\
0.040\end{array}$ & 0.008 & 99.949 \\
\hline (9) & 0.005 & $\begin{array}{r}(0.05) \\
0.054\end{array}$ & 0.008 & 99.933 \\
\hline$(10)$ & 0.003 & $\begin{array}{r}(0.08) \\
0.094\end{array}$ & 0.009 & 99.894 \\
\hline (11) & 0.006 & $\begin{array}{r}(0.10) \\
0.113\end{array}$ & 0.009 & 99.872 \\
\hline$(12)$ & 0.005 & 0.005 & $\begin{array}{l}(0.01) \\
0.022\end{array}$ & 99.968 \\
\hline$(13)$ & 0.002 & 0.008 & $\begin{array}{l}(0.03) \\
0.052\end{array}$ & 99.938 \\
\hline (14) & 0.002 & 0.008 & $\begin{array}{l}(0.05) \\
0.084\end{array}$ & 99.906 \\
\hline (15) & 0.002 & 0.009 & $\begin{array}{l}(0.08) \\
0.123\end{array}$ & 99.866 \\
\hline (16) & 0.002 & 0.009 & $\begin{array}{r}(0.10) \\
0.144\end{array}$ & 99.845 \\
\hline$(17)$ & $\begin{array}{r}(0.03) \\
0.025\end{array}$ & $\begin{array}{r}(0.03) \\
0.027\end{array}$ & $\begin{array}{r}(0.03) \\
0.066\end{array}$ & 99.882 \\
\hline (18) & $\begin{array}{r}(0.05) \\
0.054\end{array}$ & $\begin{array}{r}(0.05) \\
0.052\end{array}$ & $\begin{array}{r}(0.05) \\
0.080\end{array}$ & 99.814 \\
\hline
\end{tabular}

( ) Intended composition.

of one per cent solution of $\left(\mathrm{NH}_{4}\right)_{2} \mathrm{~B}_{4} \mathrm{O}_{7}$ whose capacity is one litre, is placed in a water bath in which fresh water is circulated to keep the temperature constant. The cell is composed of an aluminium foil electrode $S_{1}$ of $50 \mathrm{~mm}$ square to be tested and a cathode $\mathrm{S}_{2}$ of the same size made of commercial the mother alloys were melted in a crucible furnace, and it was cast in a sheet ingot 30 $\mathrm{mm} \times 100 \mathrm{~mm} \times 150 \mathrm{~mm}$ in size, the content of each impurity being varied from 0.02 to 0.10 per cent. The intended composition and the results of analysis are shown in Table 2. After heat treatment, the surface of sheet ingot was scalped and they were rolled down to the foil of $0.1 \mathrm{~mm}$ in thickness as follows:

Sheet ingot $30 \mathrm{~mm} \times 100 \mathrm{~mm} \times 150 \mathrm{~mm}$.

Annealed at $440^{\circ}$ for 7 hours.

Scalped on its both surfaces by $1.5 \mathrm{~mm}$.

Cold-rolled to $6 \mathrm{~mm}$ in thickness.

Annealed at $420^{\circ}$ for 8 hours.

Cold-rolled to $\underset{\downarrow}{\downarrow} 0.6 \mathrm{~mm}$ in thickness.

Annealed at $380^{\circ}$ for 8 hours.

Cold-rolled to $0.1 \mathrm{~mm}$ in thickness.

\section{Description of Apparatus}

The arrangement of apparatus is shown in Fig. 1. The cell B, containing the elctrolyte

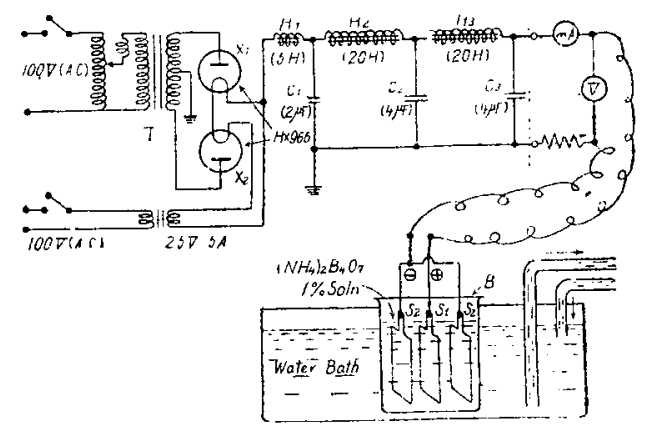

Fig. 1 Apparatus for Formation Test of Dielectric Film of Electrolytic Condenser. 
aluminium. The supplied voltage is regulated by a tapped auto-transformer $T$.

\section{Method of Experiment}

In general, it is said the higher the purity of aluminium, the more rapid the formation of dielectric film and the lower the resultant leakage current are. Therefore, the specimens were annealed at $350^{\circ}$ for one hour and they were electro-chemically degreased for 60 seconds in a $\mathrm{Na}_{2} \mathrm{CO}_{3} 10$ per cent solution at $25^{\circ}$. And they were anodically oxidized in the apparatus shown in Fig. 1. with a definite current of $20 \mathrm{~mA} /$ $\mathrm{dm}^{2}$. Increasing the voltage, the anodized film was gradually formed on the specimen and the voltage-time curves were obtained up to $300 \mathrm{~V}$ at an interval from one to five minutes. After the formation of the film, its voltage was kept at $300 \mathrm{~V}$ and the changes of leakage current were measured at the same interval and its value 30 minutes after was adopted as the standard of leakage current.

In order to ascertain the annealing effect on the formation, the same experiments were made on the hard specimens. Although it is well known that a small variation in temperature in electrolyte has no effect on the formation of the dielectric film, endeavours were made to keep the temperature at $16 \sim 18^{\circ}$.

\section{Results of Experiment}

The voltage-time curves obtained on the annealed specimen are shown, as examples, in Fig. 2. The relation between the voltage and time is seen to be almost linear, but,

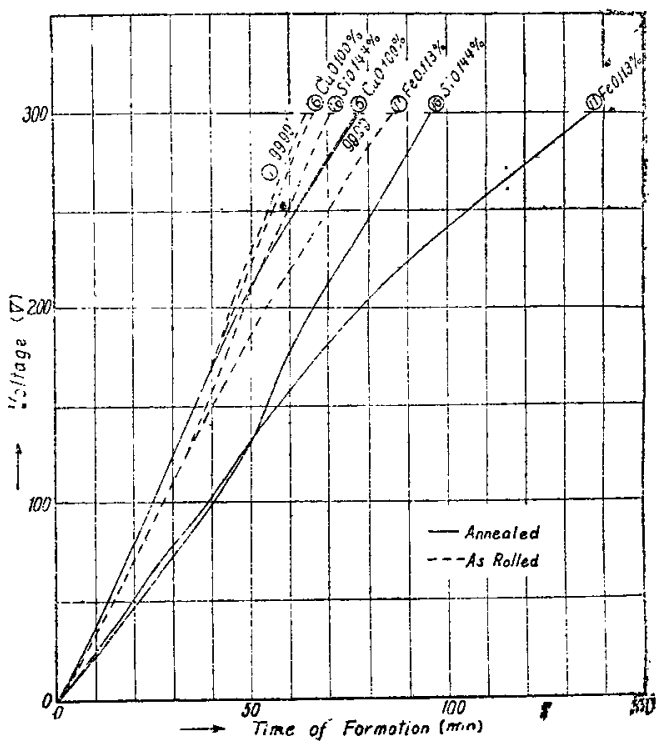

Fig. 2 Relation between Voltage and Time of Formation.

(Current Density of Formation...20 $\mathrm{mA} / \mathrm{dm}^{2}$ )

(Electrolyte...1\% $\left(\mathrm{NH}_{4}\right)_{2} \mathrm{~B}_{4} \mathrm{O}_{7}$ Soln.) in the case of specimen with 0.1 per cent iron, the curve shows a tendency to decline from a certain point. The time required to reach $300 \mathrm{~V}$ in the specimen of 99.99 per cent purity was about 78 minutes; on the other hand, that of the

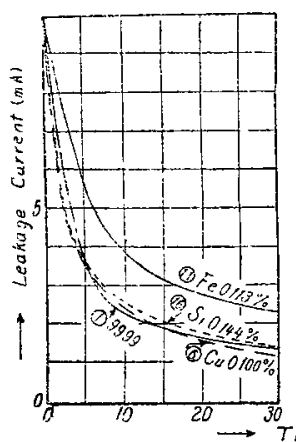

(As Rolled)

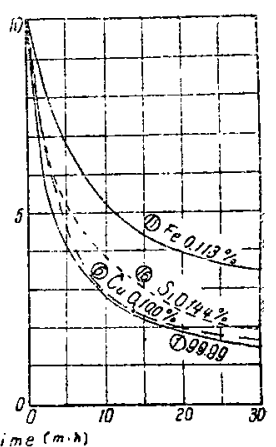

(Annealed)

Fig. 3 Changes of Leakage Current for 30 Minutes After Formation to $300 \mathrm{~V}$.

specimen with 0.1 per cent iron was about 135 minutes. Comparing one another the specimens containing the impurities of iron, silicon and copper, it was found that the specimen containing iron as impurity took longer time to reach $300 \mathrm{~V}$. The leakage current decreased gradually with time and reached almost constant value in 30 minutes as shown in Fig. 3 .

From these experiments, it was found that iron had the worst effect, and that 
silicon and copper had almost no effect. Then the voltage-time: curves and the leakage current-time curves were measured in all specimens and their results are summarized as shown in Fig. 4 and 5 . In the case of hard specimen, similar results were obtained, namely, iron gave the worst effect as shown in Fig. 2 and 3 and the formation of dielectric film on hard specimen was more rapid than that of annealed one.

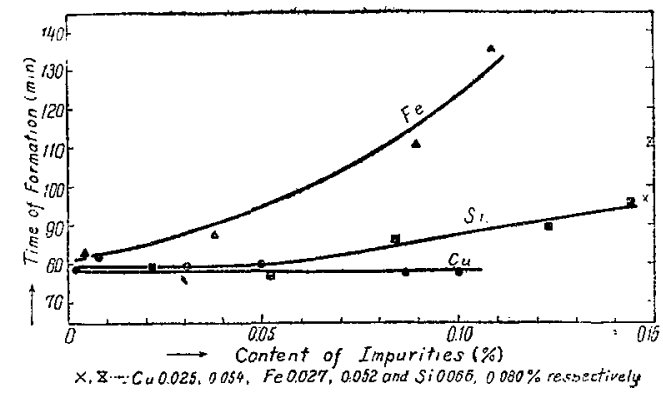

Fig. 4 Relation between Time of Formation and Content of Impurities in High Purity Aluminjum Foil. (Annealed)

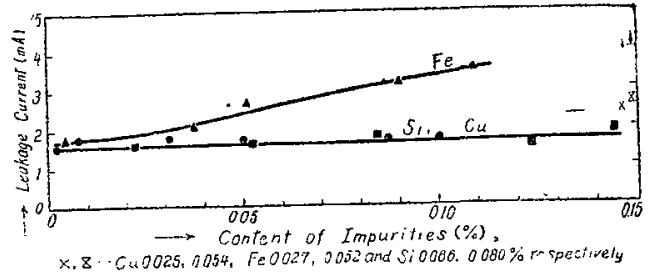

Fig. 5 Relation between Leakage Current and. Content of Impurities in High Parity Aluminim Foil. (Amealed)

From these tests, the following results are ascertained within the scope of the present experiments :

(1) Copper has no effect on the time required for the formation of the film and on the leakage current.

(2) Silicon has also no effect on the leakage current, but above 0.05 per cent it has a little effect on the time of formation.

(3) Iron is especially unfavaourable, and as little as 0.03 per cent gives a remarkable bad effect on the time required for the formation and on the leakage current.

(4) It is supposed that the composite impurities of iron, silicon and copper will give a slightly bad effect as compared with iron only, and the phenomenon seems to depend mainly upon the effective iron content.

(5) The formation of the film on hard specimen is more rapid than that of annealed one, but there is no difference in the leakage current between them.

It is very interesting to investigate the influence of annealing temperature and grain size on the formation of the dielectric film, but the present experiments has not yet been completed to publish it.

\section{Consideration}

As above mentioned, it was found that iron had a strong effect on the formation of the dielectric film, and that silicon and copper had 'no remarkable effect. The solubility of iron in aluminium is $0.006 \%^{(5)}$ at $500^{\circ}$ and supposed to be nearly zero at room temperature, so that if iron exists in aluminium even less than $0.03 \%$, good oxidized film will not be formed in the vicinity of iron particles and its compounds, and its film cannot completely protect a leakage current through the iron compounds. Silicon and copper, however, are comparatively soluble in aluminium at the room temperature, so they have almost no effect on the formation of oxidized film up to a solubility limit. The solubility of silicon in aluminium at $200^{\circ}$ is about 0.05 per cent $t^{(6)}$ and those of copper at the room temperature is 0.5 per cent ${ }^{(7)}$.

(5) J.K.Edgar, Metal Technology, 15(1948),No. 4.

(6) Dix \& Heath, Div. Amer. Inst. Min. \& Met. Eng., (1928), 164.

(7) Dix \& Richardson, Trans. Amer. Inst. Min. \& Met. Eng., 7Z(1926),560. 
It is supposed then that the impurities existing in the form of precipitate or compound have a strong effect, but those in the form of solid solution have no effect on the dielectric film of electrolytic condenser.

\section{Conclusion}

From the present investigation, the authors obtained the following results.

(1) Increasing the impurity of iron in aluminium, the property of its dielectric film grows to be inferior, that is, the time of formation will be longer and the leakage current higher. It will be better if iron content in high purity aluminium of the electrolytic condenser could be limited to less than 0.03 per cent.

(2) Silicon has no effect up to 0.05 per cent which is a maximum content in high purity aluminium.

(3) Copper has no effect up to 0.10 per cent. This exceeds the maximum content in high purity aluminium.

(4) The hard aluminium gives a better dielectric film than annealed one.

It is further found that small amounts of the impurities dissolved in solid solution have no effect, and that the existence of iron has a strong effect on the dielectric properties. Therefore, iron content should be limited as small as possible in comparison with silicon and copper in high purity aluminium used for electrolytic condenser.

The authors are indebted to Dr. H. Nishimura of the Department of Metallurgy, Kyôto University, for his alvice in this research. 